\title{
Electrophysiological Properties of Octopus Neurons of the Cat Cochlear Nucleus: an In Vitro Study
}

\author{
RAMAZAN BAL ${ }^{1}$ AND GIYASETTIN BAYDAS ${ }^{2}$ \\ ${ }^{1}$ Department of Biophysics, Faculty of Medicine, Firat University, 23119, Elazig, Turkey \\ ${ }^{2}$ Department of Physiology, Faculty of Medicine, Firat University, Elazig, Turkey
}

Received: 3 October 2008; Accepted: 5 February 2009; Online publication: 11 March 2009

\begin{abstract}
Electrophysiological studies from mice in vitro have suggested that octopus cells of the mammalian ventral cochlear nucleus (VCN) are anatomically and biophysically specialized for detecting the coincident firing of a population of auditory nerve fibers. Recordings from cats in vivo have shown that octopus cells fire rapidly and with exceptional temporal precision as they convey the timing of that coincidence to higher auditory centers. The current study addresses the question whether the biophysical properties of octopus cells that have until now been examined only in mice, are shared by octopus cells in cats. Whole-cell patch-clamp recordings confirm that octopus cells in brain slices from kittens share the anatomical and biophysical features of octopus cells in mice. As in mice, octopus cells in kittens have large cell bodies and thick dendrites that extend in one direction. Voltage changes produced by depolarizing and hyperpolarizing current injection were small and rapid. Input resistances and membrane time constants in octopus cells of 16-day-old kittens were $15.8 \pm$ $1.5 \mathrm{M} \Omega(n=16)$ and $1.28 \pm 0.3 \mathrm{~ms}(n=16)$, respectively. Octopus cells fired only a single action potential at the onset of a depolarizing current pulse; suprathreshold stimuli were greater than $1.8 \mathrm{nA}$. A tetrodotoxin (TTX)-sensitive sodium conductance $\left(g_{\mathrm{Na}}\right)$ was responsible for the generation of the action potentials. Octopus cells displayed outward rectification that lasted for the duration of the depolarizing pulses. Hyperpolarizations produced by the injection of current exhibited a depolarizing sag of the membrane
\end{abstract}

Correspondence to: Ramazan Bal · Department of Biophysics, Faculty of Medicine · Firat University · 23119, Elazig, Turkey. Telephone: +90-424-2370000; fax: +90-424-2379138; email: rbal1969@gmail.com, email: rbal@firat.edu.tr potential toward the resting value. A 4-aminopyridine (4-AP) and $\alpha$-dendrotoxin ( $\alpha$-DTX)-sensitive, lowvoltage-activated potassium conductance $\left(g_{\mathrm{KL}}\right)$ and a ZD7288-sensitive, mixed-cation conductance $\left(g_{\mathrm{h}}\right)$ were partially activated at rest, giving the octopus cells low input resistances and, as a consequence, brief time constants. In 7-day-old kittens, action potentials were taller and broader, input resistances higher, and both inward and outward rectification was weaker than in 16-day-old kittens. Also as in mice, stellate cells of the VCN fired trains of action potentials with constant interspike intervals when they were depolarized $(n=10)$ and bushy cells of the VCN fired only a single action potential at the onset of depolarizations $(n=6)$. In conclusion, the similarity of octopus cells in mice and kittens suggests that the anatomical and biophysical specializations that allow octopus cells to detect and convey synchronous firing among auditory nerve fibers are common to all mammals.

Keywords: auditory pathways, cochlear nucleus, octopus cell, patch clamp, cat

\section{INTRODUCTION}

Octopus cells lie in the most caudal and dorsal part of the ventral cochlear nucleus (VCN), the octopus cell area, where auditory nerve fibers bundle closely together as they exit the VCN and enter the deep layer of the dorsal cochlear nucleus (DCN) in all mammalian species including humans (Osen 1969; Kane 1973; Brawer et al. 1974; Adams 1986; Hackney et al. 1990; Morest et al. 1990). Activity in auditory nerve fibers activates glutamate receptors of the 
AMPA subtype that have rapid kinetics (Gardner et al. 1999). Octopus cells give rise to one of the major ascending pathways from the VCN, projecting to the superior paraolivary nucleus and to the contralateral ventral nucleus of the lateral lemniscus (VNLL) (Adams and Warr 1976); Schofield 1995; Schofield and Cant 1997). Octopus cells terminate in calyceal end bulbs in the VNLL in cats and humans (Adams 1997). Octopus cells have large cell bodies; few, sparsely branched, thick dendrites that taper gradually emerge from one pole of the cell body. In mice the axis of the tonotopic organization lies approximately in the parasagittal plane (Wickesberg and Oertel 1988); dendrites of octopus cells spread across the tonotopically organized bundle of auditory nerve fibers so that fibers that encode low frequencies terminate near the cell body and fibers with progressively higher best frequencies terminate increasingly distally (Golding et al. 1995, 1999). In cats, the tonotopic axis twists in the posteroventral cochlear nucleus (PVCN) so that the relationship between the morphology of octopus cells and tonotopy is more difficult to observe (Snyder and Leake 1988).

Recordings from cats in vivo have shown that octopus cells are broadly tuned. Their broad tuning reflects the anatomical organization that allows octopus cells to integrate inputs from large populations of auditory nerve fibers. These cells present a sharp peak at the stimulus onset in the poststimulus time histogram (PSTH); in response to clicks, to periodic sounds, and to the onset of tones, octopus cells fire action potentials at high rates (up to $800 / \mathrm{s}$ ) and little temporal jitter $(<200 \mu \mathrm{s}) \quad$ (Godfrey et al. 1975; Ritz and Brownell 1982; Rhode et al. 1983; Rhode and Smith 1986; Oertel et al. 2000; Smith et al. 2005).

Recordings from mice in vitro have demonstrated that octopus cells have exceptionally large mixedcation conductances $\left(g_{\mathrm{h}}\right)$ and low-voltage-activated potassium conductances $\left(g_{\mathrm{KL}}\right)$ (Golding et al. 1995, 1999; Bal and Oertel 2000, 2001). They respond to the synchronous activation of populations of auditory nerve fibers with brief, sharply timed, synaptic responses (Golding et al. 1995; Oertel 1997). The sharp timing is made possible by the low input resistance (about $7 \mathrm{M} \Omega$ ) and short time constant (about $200 \mu \mathrm{s}$ ) that generate EPSPs that are barely longer than EPSCs (about $1 \mathrm{~ms}$ in duration), from the reduction of jitter by the summation of many inputs, and by the sharpening of EPSPs by $g_{\mathrm{KL}}$ (Golding et al. 1995, 1999; Bal and Oertel 2000, 2001; Cao and Oertel 2005; Ferragamo and Oertel 2002; McGinley and Oertel 2006)).

The goal of the present study was to determine whether the unusual properties of octopus cells that have been measured in mice also exist in cats, the species in which most in vivo recordings have been made. These two experimental animals live in different environments, are predator and prey, respectively, and hear over different but overlapping, frequency ranges (Ehret 1977; Fay 1988; Heffner and Hefner 2007). Our recordings from kittens show that the electrophysiological properties of octopus cells, as well as stellate and bushy cells, are similar to those of mice.

\section{METHODS}

\section{Brain slice preparation}

The experimental protocols were approved by the local animal use committees of the University of Mustafa Kemal (Antakya) and the University of Firat (Elazig). Animal care and experimental protocols complied with the "Guide for the Care and Use of Laboratory Animals". Kittens were obtained from the Firat University Animal Unit. Coronal slices of the cochlear nucleus $(\mathrm{CN})$ were prepared from three 7-day-old cats and ten 15- or 16-day-old cats. After the kittens had been deeply anesthetized with ketamine $(25 \mathrm{mg} / \mathrm{kg})$ and xylazine $(1 \mathrm{mg} / \mathrm{kg})$, a craniotomy was made and the whole brain was quickly removed and immersed in oxygenated physiological saline in a large dissecting chamber. The brain was cut coronally at the midcollicular level and the rostral surface of the caudal part of the brain containing the $\mathrm{CN}$ was mounted on a Teflon block with cyanoacrylate glue (Superglue). Slices of $175-\mu \mathrm{m}$ thickness were cut with a vibrating microtome (Leica VT 1000S) and then were transferred to a storage chamber containing fresh, oxygenated, physiological saline at $30^{\circ} \mathrm{C}$ to allow the slices to recover for up to $2 \mathrm{~h}$. The procedure from craniotomy of the animals to completion of the brainstem slices took about $10 \mathrm{~min}$. For recording, the slices were transferred to a chamber having a volume of about $0.3 \mathrm{ml}$ through which oxygenated saline was continuously perfused at about $5 \mathrm{ml} / \mathrm{min}$. The temperature of the perfusing saline in the recording chamber was kept at $33^{\circ} \mathrm{C}$.

Cells in slices were visualized with differential interference contrast (DIC) optics (Axioscope FS, Zeiss) through a $\times 63$ water immersion objective. Octopus cells were initially identified in coronal slices by their large size and characteristic location in a triangular region of heavily myelinated fibers in the most caudal and dorsal portion of the VCN and were found to have biophysical properties similar to those in mice (Golding et al. 1995, 1999). Following recordings with pipettes that contained biocytin, they were also confirmed as octopus cells by their characteristic morphology. Pipettes were filled with a solution that contained $0.1 \%$ biocytin. After the final records were collected, fixative was introduced into the recording chamber for $5 \mathrm{~min}$ before the pipette was removed 
from the cell to minimize damage to cells in the withdrawing of the pipette (Cao et al. 2007). Slices were stored in the fixative, $2 \%$ glutaraldehyde and $2 \%$ paraformaldehyde, in $0.1 \mathrm{M}$ sodium phosphate buffer at $4^{\circ} \mathrm{C}$. The slices were then incubated for $2-3 \mathrm{~h}$ at $20^{\circ} \mathrm{C}$ with avidin conjugated to horseradish peroxidase (HRP) (Vector ABC kit, Vector Laboratories, Burlingame, CA, USA). The HRP was reacted using the DAB-nickel/cobalt intensification method (Bal et al. 2002). The sections were mounted on slides and counter-stained with neutral red. Labeled cells were reconstructed with a camera lucida using a $\times 100$ objective.

\section{Solutions and drugs}

The physiological saline contained (in $\mathrm{mM}$ ): 130 $\mathrm{NaCl}, 3 \mathrm{KCl}, 1.2 \mathrm{KH}_{2} \mathrm{PO}_{4}, 2.4 \mathrm{CaCl}_{2}, 1.3 \mathrm{MgSO}_{4}, 20$ $\mathrm{NaHCO}_{3}, 3$ HEPES, 10 glucose, saturated with $95 \%$ $\mathrm{O}_{2} / 5 \% \mathrm{CO}_{2}, \mathrm{pH} 7.4$, between 25 and $33^{\circ} \mathrm{C}$ (Bal and Oertel 2000). In current-clamp experiments involving the use of $\mathrm{Cd}^{2+}$ and 4-aminopyridine (4-AP), the external solution contained (in $\mathrm{mM}$ ): $138 \mathrm{NaCl} ; 3$ $\mathrm{KCl}, 2.4 \mathrm{CaCl}_{2}, 1.3 \mathrm{MgCl}_{2}, 10$ HEPES, 10 glucose, and $\mathrm{pH}$ 7.4. Test solutions were applied to the chamber by redirecting the flow of liquid through a system of tubing and valves.

Pipettes were generally of low resistance (4-7 M 2 ). They were pulled from borosilicate glass (1.2 mm OD) and were filled with a solution containing (in $\mathrm{mM}$ ): 110 potassium gluconate, 9 HEPES, 9 EGTA, $4.5 \mathrm{MgCl}_{2}, 14$ phosphocreatinine (tris salt), 4 ATP (Na-salt) and 0.3 GTP (tris salt); the pH was adjusted to 7.4 with $\mathrm{KOH}$ (Forscher and Oxford 1985). Tetrodotoxin (TTX) was purchased from Alexis Biochemicals (USA), 4-(Nethyl$N$-phenylamino)-1,2-dimethyl-6-(methylamino) pyridinium chloride (ZD7288) from Tocris Cookson, UK, $\alpha$-DTX from Alomone Labs (Israel), and other chemicals were obtained from Sigma.

\section{Whole cell recordings and data acquisition}

Current-clamp recordings were performed with standard whole-cell patch-clamp techniques using an Axopatch-200A amplifier. Data were low-pass-filtered at $5-10 \mathrm{kHz}$. Current and voltage records were sampled at $10-40 \mathrm{kHz}$ and were digitized online using a Digidata 1440 interface (Axon Instruments, Foster City, CA, USA) and an IBM-compatible personal computer for storage and further analyses. Stimulus generation, data acquisition, and off-line analysis of digitized data were done using pClamp software (version 10, Axon Instruments). After the formation of high resistance seals $(>1 G \Omega)$ negative pressure was applied to obtain the whole cell configuration. All recordings have been compensated for a junction potential of $-12 \mathrm{mV}$. Data are expressed as mean \pm standard error, with $n$ being the number of cells in which the measurement was made. Statistical comparison of basic biophysical properties of octopus neurons in 7-day-old and 15- or 16-day-old cats was performed using the nonparametric Mann-Whitney $U$ test. $P$ value $<0.05$ was considered to be statistically significant.

\section{RESULTS}

Data reported here were obtained from recordings of 21 octopus cells, ten stellate cells, and six bushy cells from 13 cats, of which eight octopus cells, three stellate cells and three bushy cells were anatomically identified. Of the 21 octopus cell recordings, five were obtained from two 7-day-old kittens and the remainder were obtained from 15- or 16-day-old kittens and all the recordings from stellate and bushy cells were obtained from 15- or 16-day-old kittens. The recordings lasted between $20 \mathrm{~min}$ and $3 \mathrm{~h}$. All the biocytinstained octopus cells responded to depolarizing current pulses with a single action potential at the onset, as is typical in the mouse (Golding et al. 1995, 1999; Bal and Oertel 2000, 2001, 2007, Cao and Oertel 2005). We concluded, therefore, that octopus cells could be identified physiologically in cats as in mice.

\section{Morphology}

In coronal slices of the cochlear nuclei of kittens, the octopus cells from which recordings were made were located in the most dorsal and caudal tail of the VCN where auditory nerve fibers bundle closely. The biocytin-labeled octopus cells closely resembled those described in the literature (Osen 1969; Kane 1973; Brawer et al. 1974; Rhode et al. 1983; Rouiller and Ryugo 1984; Smith et al. 2005). Figure 1 shows photomicrographs of two octopus cells labeled with an intracellular injection of biocytin. These cells had large, irregularly shaped cell bodies (31-39 $\mu \mathrm{m}$ in diameter) with three to five thick primary dendrites (up to $9 \mu \mathrm{m}$ in diameter) emerging from only one side of the cell body. In five of eight biocytin-labelled neurons, the primary dendrites divided into secondary dendrites and then terminated as short and tapering tertiary dendrites with endings having large swellings and a thorny appearance (Fig. 1B(1), B(2)). In three other biocytin-labeled octopus cells, the tertiary dendrites were also gradually tapering but lacked terminal enlargements (Fig. 1A). On the surface of the cell bodies of two densely stained octopus cells somatic spines were visible but no dendritic spines were observed. 

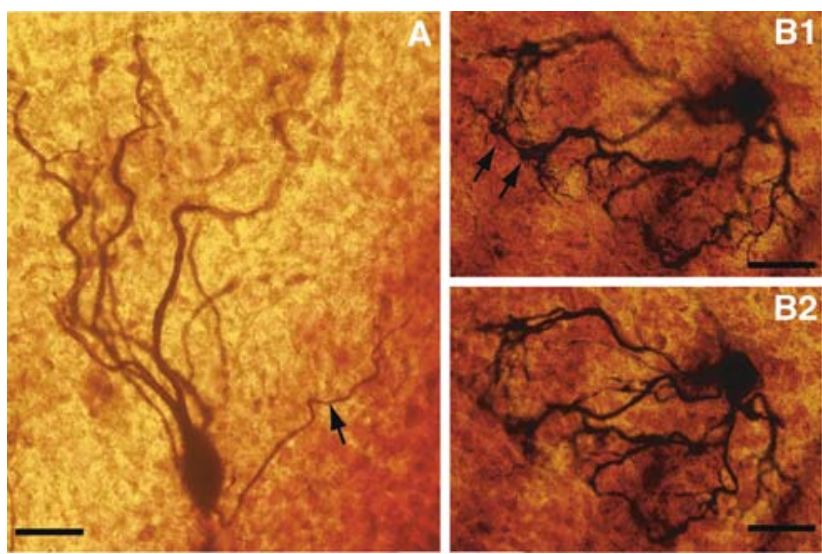

FIG. 1. Photomicrographs of two octopus cells labeled intracellularly with biocytin in $175-\mu \mathrm{m}$ thick-coronal slice preparations counter-stained with neutral red. A The octopus cell had three long primary dendrites emerging from dorsal part of the soma. The arrow indicates the axon. Calibration, $40 \mu \mathrm{m}$. B 1 and B 2 another biocytinstained octopus cell from a different animal. In $\mathbf{B} 1$, the focus was adjusted to see the tip of the dendrites and in $\mathbf{B} 2$ the focus was adjusted to show the cell body. Note that dendritic endings indicated by the arrows had a thorny appearance. Calibration, $45 \mu \mathrm{m}$.

Where they could be followed axons headed dorsally for a short distance, presumably on their way to the intermediate acoustic stria. No axonal collaterals were observed; it is impossible to know whether cats lack axonal collaterals or whether axons were cut too near the cell body to observe them in the thin slices $(175 \mu \mathrm{m})$.

The dendritic trees of octopus cells were usually oriented perpendicular to the auditory nerve fibers. Reconstructions of two octopus neurons are illustrated in Figure 2A, B. The dendritic trees of six octopus cells including the one shown in Figure 2A were oriented so that their tips extended dorsally and laterally from the cell body.

\section{Physiology}

In slices from 15- and 16-day-old cats, octopus cells had a mean resting membrane potential of $-59.4 \pm$ $0.4 \mathrm{mV}(n=16)$. The mean input resistance, calculated from a linear fit of the negative section of the current-voltage relationship of the peak voltage responses near rest was $15.8 \pm 1.5 \mathrm{M} \Omega(n=16)$. The mean time constant for hyperpolarizing responses close to the resting potential was $1.28 \pm 0.3 \mathrm{~ms}(n=16)$. The amplitude of action potentials was $43.1 \pm 3.0 \mathrm{mV}$ $(n=16)$. The mean duration of action potentials, measured halfway between the peak and the inflection point, was $0.32 \pm 0.03 \mathrm{~ms}(n=16)$. The latencies from the onset of the current pulse to the peaks of action potentials evoked with depolarizing currents of $4 \mathrm{nA}$ were $0.62 \pm 0.03 \mathrm{~ms}(n=16)$.
The input resistances were significantly greater $(p<$ $0.01)$ and the time constants were significantly longer $(p<0.05)$ in the 7-day-old than those in 15- and 16-dayold kittens. In the 7-day-old animals, the mean resting membrane potential was $-59.2 \pm 0.9 \mathrm{mV}(n=5)$; the mean input resistance, $24.1 \pm 5.7 \mathrm{M} \Omega(n=5)$; the mean time constant, $3.6 \pm 1.5 \mathrm{~ms}(n=5)$; the amplitude of action potentials, $56.3 \pm 6.6 \mathrm{mV}(n=5)$; the mean duration of action potentials, $0.5 \pm 0.07 \mathrm{~ms}(n=5)$ and the latencies from the onset of the current pulse to the peaks of action potentials, $0.74 \pm 0.05 \mathrm{~ms}(n=5)$.

A

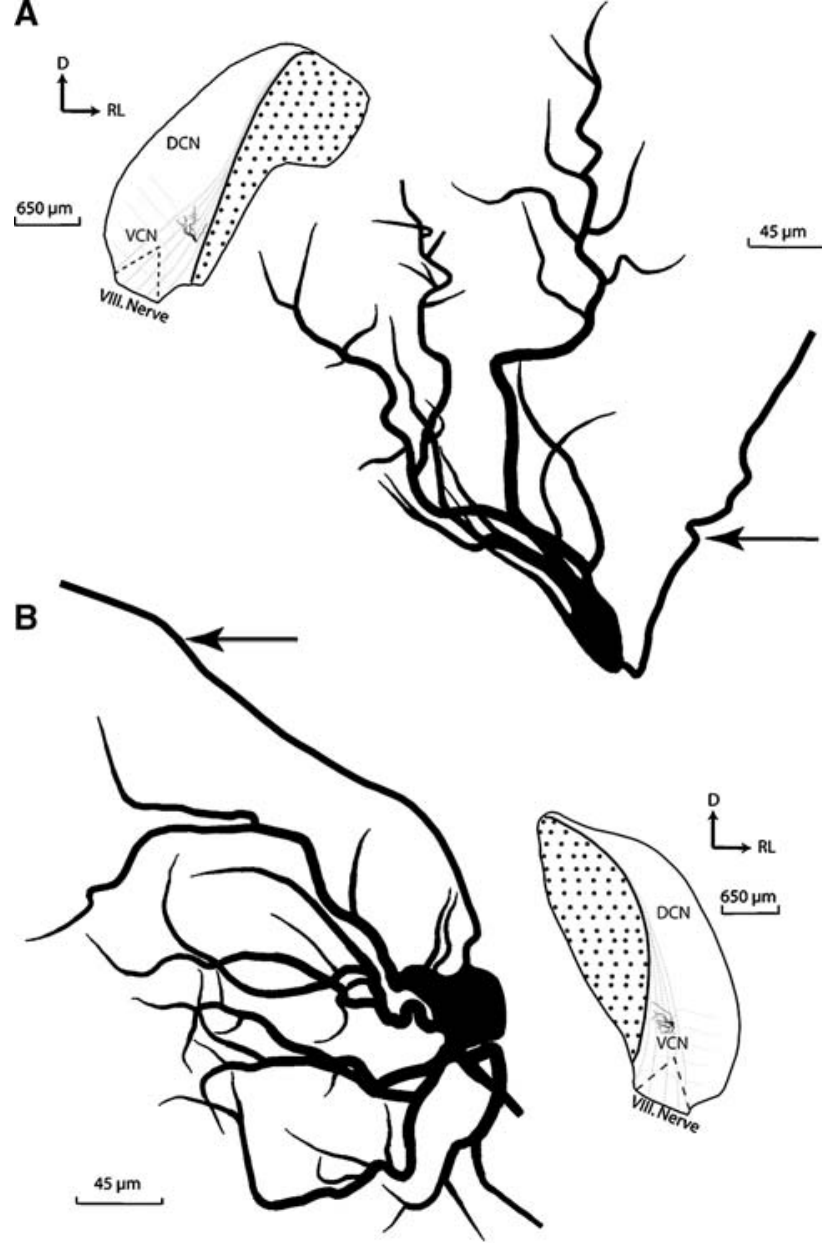

FIG. 2. Morphological reconstruction of two biocytin-labelled octopus cells located in the PVCN. A The cell whose photomicrograph is shown in Figure 1A is presented in (A) and another biocytinlabelled octopus cell is given in (B). The inset shows the location of the octopus cell with respect to VCN and DCN in the schematic version of cat cochlear nuclear complex in a coronal section. The dotted area is the part of the brain stem surrounded by the $\mathrm{CN}$. Each octopus cell was characteristically located in a triangular region of heavily myelinated fibers just ventral and caudal to the translucent granule cell layer that separates the ventral from the dorsal $\mathrm{CN}$. The light dashed lines represent the bundles of the auditory nerve fibers, which appear less bright compared to the DCN region under the microscope during recordings. The axon is indicated with an arrow. 
Figure 3 contrasts traces and voltage-current relationships between octopus cells in 7- and 15-dayold kittens. The input resistances were $21.7 \mathrm{M} \Omega$ and 13.5 M $\Omega$ for 7- and 15-day-old kittens, respectively. Time constants were 3.5 and $1.2 \mathrm{~ms}$ for 7- and 15-dayold kitten, respectively. In 15-and 16-day-old kittens, the voltage changes produced by depolarizing and hyperpolarizing current pulses are smaller and briefer as a consequence of a lower input resistance and a shorter time constant compared to those in 7-day-old preparation. Octopus cells generally required more than $1.8 \mathrm{nA}$ to evoke action potentials and fired only a single action potential at the onset of a depolarizing current pulse. Outward rectification lasted for the duration of the depolarizing pulse (Fig. 3A(1), B(1)). The voltage-current relationships, plotted from the steady-state levels, were nonlinear over the whole depolarizing current range. The nonlinearity of the $\mathrm{I} / \mathrm{V}$ relationships was more prominent in 15- and 16-day-old cats than in 7-day-old kittens (Fig. 3A(2), $B(2))$. Action potentials were taller and broader in octopus cells from younger than older kittens.

All the octopus cells tested with the injection of hyperpolarizing current exhibited a depolarizing sag of the membrane potential towards the resting value. The amplitude of the sag increased with the amplitude of hyperpolarizing current pulses as did a depolarizing overshoot after the end of the current pulse that could evoke a rebound action potential in most cells (Fig. 3B(1)). The finding that hyperpolarization can lead to a depolarizing rebound suggests that hyperpolarization activated a voltage-dependent conductance that has a depolarized reversal potential as does $g_{\mathrm{h}}$ in octopus cells of mice (Bal and Oertel 2000). Comparisons between 15- and 7-day-old kittens show that the sag became more prominent with age and the action potentials became briefer and shorter (Fig 3A(1), B(1)).

Octopus cells fire only one action potential at the onset of a depolarization irrespective of the amplitude of the current injected (Fig. 3A(1), B(1)). To test whether octopus cells are in an absolute refractory state after the first action potential, a second depolarization was superimposed on the first. Figure 4A shows that octopus cells can fire another action potential when the cell is depolarized with an increased current pulse on top of the first current pulse, implying that octopus cells appear to be in a relative, not absolute, refractory state after the first action potential $(n=10)$. Figure 4B illustrates the responses of an octopus cell to a train of current pulses. Octopus cells from 15and 16-day-old cats were able to fire one action potential with every pulse when presented a train of current pulses at about $800 \mathrm{~Hz}(n=8)$. The finding that octopus cells fire only once in response to long depolarizations does not preclude their being able to fire rapidly.
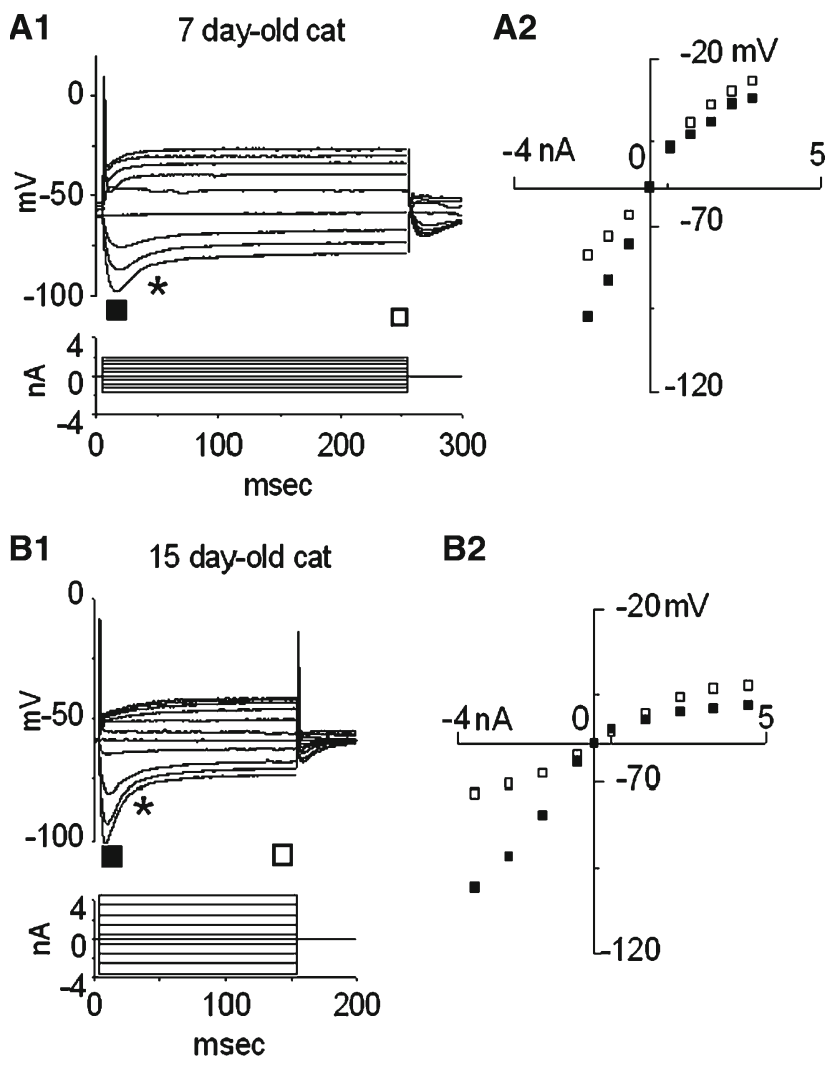

B2
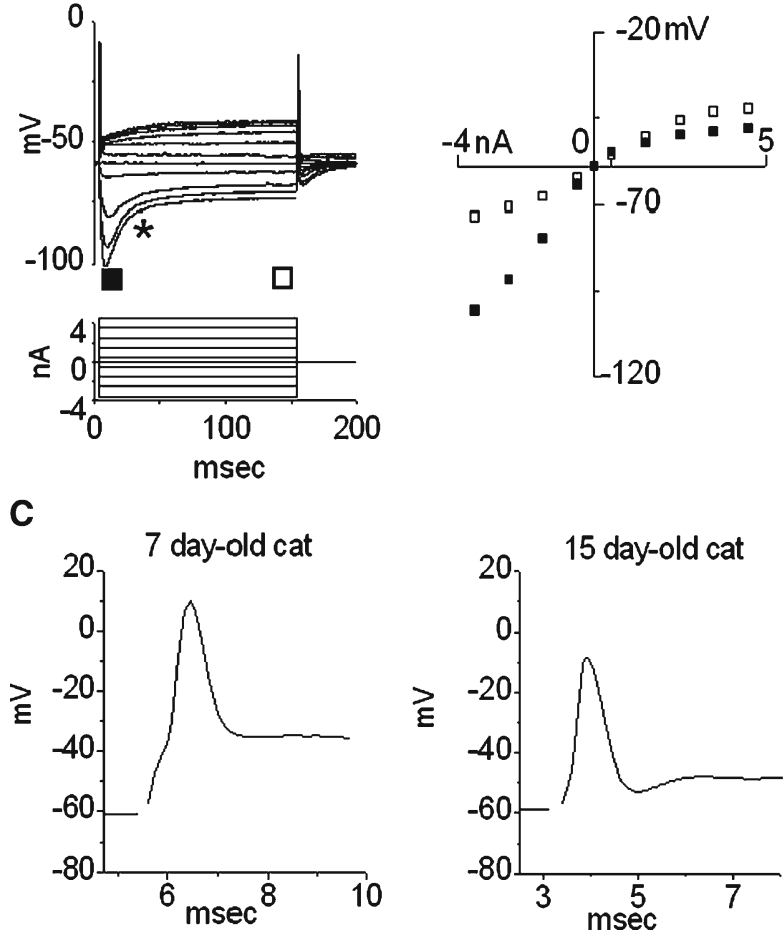

FIG. 3. Membrane properties of octopus neurons from 7 and 15-day-old cats. A 1 and $\mathbf{B} 1$ Families of superimposed responses of two octopus neurons from 7 and 15-day-old cats to current pulses (the current protocols are shown below the voltage responses). A2 and B 2 Current-voltage relationships for the same octopus cells from 7 and 15-day-old cats as in $\mathbf{A} 1$ and $\mathbf{B} 1$, respectively. The amplitude of the peak (filled square) and steady-state (unfilled square) voltage responses are plotted as a function of the injected currents. Note that in the 7-day-old cat the voltage response and time course were more pronounced compared to those of octopus neurons from the 15-day-old cat. Asterisk indicates the depolarizing sag of the membrane potential towards the resting value induced by the injection of hyperpolarizing current. $\mathbf{C}$ The single action potentials from $\mathbf{A} 1$ and B 1 are compared on expanded time scales. Note that in $\mathbf{A} 1$, $250 \mathrm{~ms}$ pulses were used, whereas, in $\mathbf{B} 1,150 \mathrm{~ms}$ pulses were used. The voltage drops across the tip resistance of the microelectrode was balanced off-line and deletion of the capacitative transient artifacts left brief gaps in the voltage traces. 

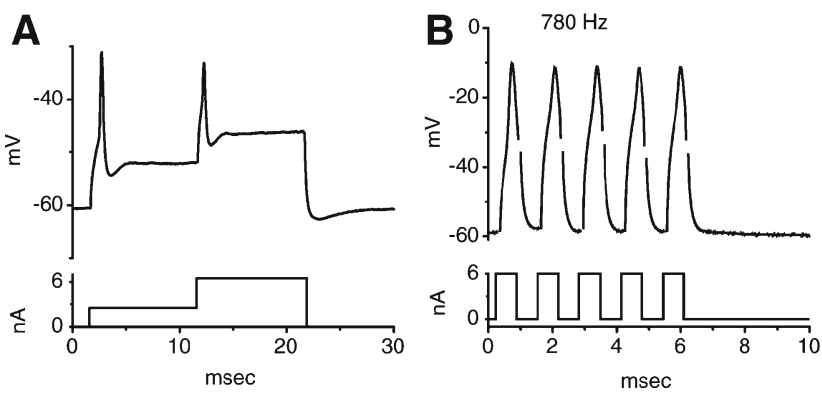

FIG. 4. A The refractory period in an octopus cell is relative, but not absolute during a depolarization with a constant DC current. The neuron from a 15-day-old cat fired a single action potential in response to a depolarization of $+2.5 \mathrm{nA}$ current. Further step depolarization from $+2.5 \mathrm{nA}$ to $+6.5 \mathrm{nA}$ caused the octopus cell to fire another action potential. B Voltage responses of an octopus cell from a 15-day-old cat to a train of depolarizing current pulses presented at $780 \mathrm{~Hz}$. The voltage drops across the tip resistance of the microelectrode were balanced off-line and deletion of the capacitative transient artifacts left brief gaps in the voltage traces.

To test whether similar conductances shape the response properties of octopus cells in the cat as in the mouse, ion channel blockers were applied to these neurons. As illustrated in Figure 5A, the addition of $1 \mu \mathrm{M}$ TTX, a specific blocker of sodium channels, eliminated the action potential nearly completely, leaving only a small depolarizing transient hump $(n=3)$. This finding suggests that the action potential is largely mediated by a regenerative sodium conductance $\left(g_{\mathrm{Na}}\right)$ (Golding et al. 1999). ZD7288, a specific and potent blocker of $g_{\mathrm{h}}$ (Khakh and Henderson 1998; Bal and Oertel 2000), abolished the sag and increased the input resistance roughly tenfold (Fig. 5B). It also made the action potentials slower, larger in amplitude, and broader. Moreover, ZD7288 caused the resting potential to become hyperpolarized by $3.5 \pm 0.5 \mathrm{mV}(n=3)$, indicating that $g_{\mathrm{h}}$ is active at rest and contributes to setting the resting potential. The voltage shift induced by ZD7288 implies that the reversal potential of the ZD7288sensitive conductance is more positive than the resting potential, as expected from a hyperpolarization-activated mixed cation current, $I_{\mathrm{h}}$. The application of 4-AP, a non-specific blocker potassium channels that blocks $g_{\mathrm{KL}}$ (Manis and Marx 1991; Golding et al. 1999; Bal and Oertel 2000, 2001; Bal et al. 2000, 2001), increased the input resistance about threefold and caused the octopus cell to become more excitable. In the presence of 4-AP, octopus cells fired larger and longer repetitive action potentials $(n=2)$ (Fig. 5C).

Figure 6 illustrates the effects of consecutively applied TTX, $\alpha$-DTX, $\mathrm{Cd}^{2+}$, and $\mathrm{Cs}^{+}$. The addition of $1 \mu \mathrm{M}$ TTX eliminated the action potential nearly completely (Fig. 6A(2)). Further addition of $30 \mathrm{nM} \alpha-$
DTX, a specific blocker of low-voltage-activated potassium channels (Bal and Oertel 2001), increased the input resistance, caused the resting potential to become depolarized by $2 \mathrm{mV}$, and caused the octopus cell to fire slower and larger repetitive action potentials (Fig. 6A(3), B(2)). The resting potential depolarized by $3.3 \pm 0.3 \mathrm{mV}$ when $50 \mathrm{nM} \alpha$-DTX was applied $(n=3)$, indicating that the conductance blocked by $\alpha$-DTX is active at rest and contributes to setting the normal resting potential. The depolarizing direction of shifts in resting potential produced by application of 4-AP and $\alpha$-DTX are consistent with the interpretation that these drugs block $g_{\mathrm{KL}}$. The input resistance increased about twofold in the depolarizing
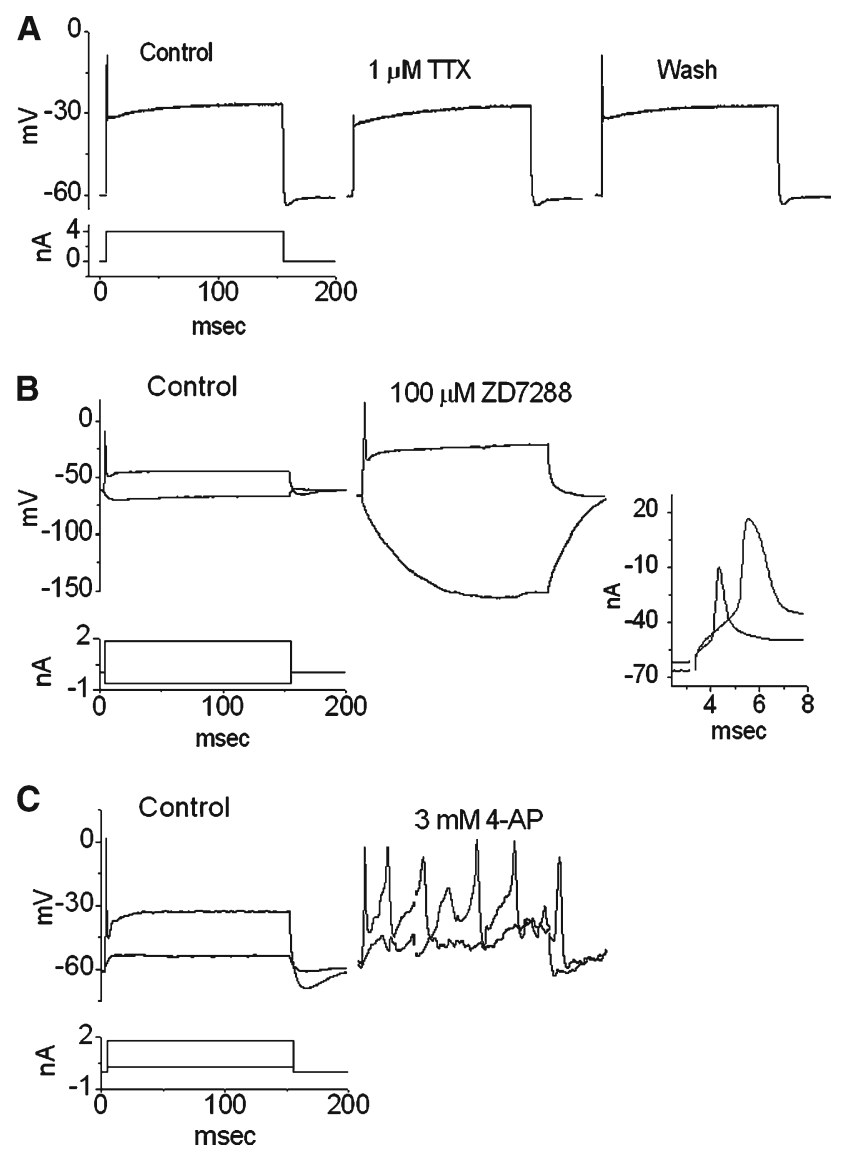

FIG. 5. Effects of TTX, ZD7288, and 4-AP on the voltage responses. A An action potential induced by a large depolarizing current step was reversibly blocked by $1 \mu \mathrm{M}$ TTX in an octopus cell from a 16-day-old cat. B Effects of ZD7288 on the voltage responses to one hyperpolarizing and one depolarizing current pulse in an octopus cell from a 15-day-old cat. The initial parts of the voltage responses are shown in the inset. Note that ZD7288 caused a hyperpolarization by $4 \mathrm{mV}$ and made the action potential slower, higher, and broader. $\mathbf{C}$ Effects of 4-AP on the voltage responses to two depolarizing current pulses in an octopus cell from another 16-day-old cat. In the presence of 4-AP, the input resistance of the cell increased. Note that the neuron became more excitable; complex calcium spikes were elicited and the membrane was hyperpolarized by $6 \mathrm{mV}$. 

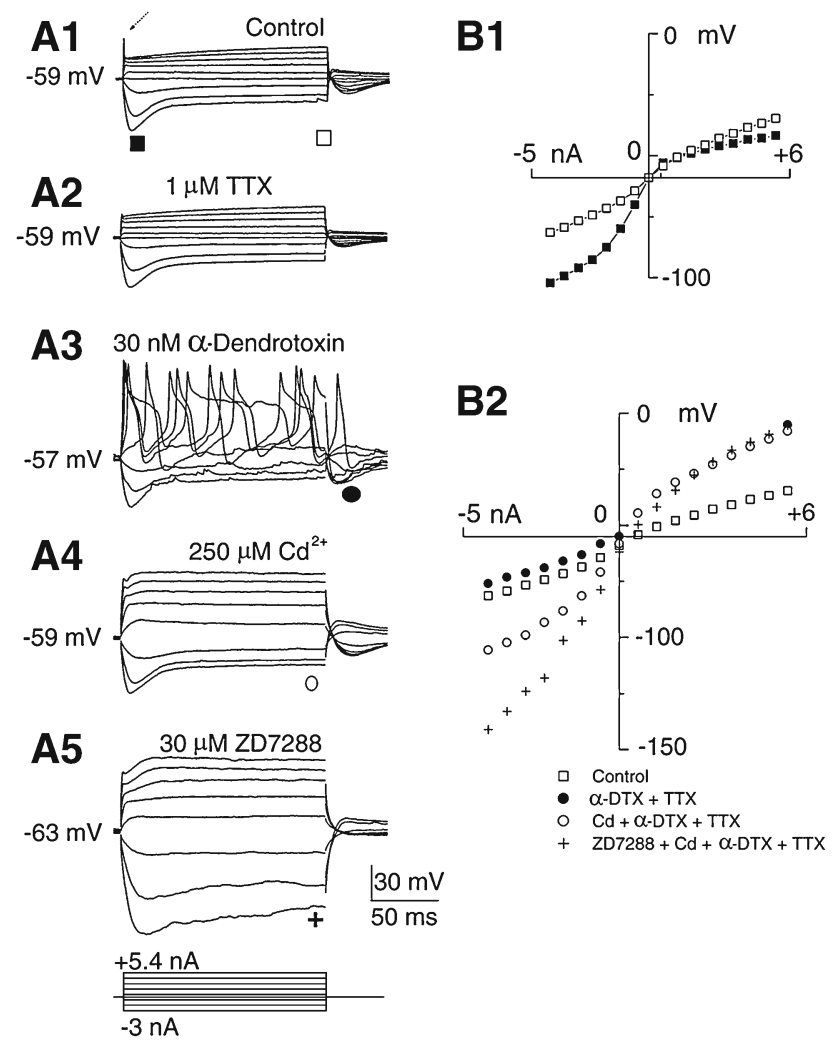

FIG. 6. Effects of consecutively applied TTX, $\alpha-\mathrm{DTX}, \mathrm{Cd}^{2+}$, and ZD7288 on the voltage responses induced by steps of depolarizing and hyperpolarizing current in an octopus cell from 15-day-old cat. A1 Families of superimposed responses to current pulses of 100-ms duration, which were recorded in normal physiological saline. Depolarizing current pulses caused the neuron to fire single action potentials shown by the arrow and hyperpolarizing current pulses produced voltage changes that sagged toward rest $\mathbf{B} 1$. The amplitude of the peak (filled square) and steady-state (unfilled square) voltage responses are plotted as a function of injected current for the recording given in A 1 . A 2 In the presence of $1 \mu \mathrm{M}$ TTX, onset action potentials were nearly completely abolished. A 3 In addition to $1 \mu \mathrm{M}$ TTX, application of $30 \mathrm{nM} \alpha$-DTX resulted in depolarizing shift of resting membrane potential and generation of multiple long-lasting action potentials of large amplitudes. Note that threshold for the induction of the action potential was lower. A4 Following TTX and $\alpha$ DTX application, application of $250 \mu \mathrm{M} \mathrm{Cd}^{2++}$ blocked the broad action potentials that appeared in the presence of TTX and $\alpha$-DTX and increased the input resistance further. A5 Following TTX, $\alpha$-DTX, and $\mathrm{Cd}^{2++}$ application, application of $30 \mu \mathrm{M}$ ZD7288 caused a hyperpolarization by $4 \mathrm{mV}$ and abolished the sag. B 2 Currentvoltage relationships for control and test conditions in the presence of $\alpha$-DTX, $\mathrm{Cd}^{2+}$, and ZD7288. The steady-state voltage responses are plotted as a function of injected currents for the recordings given in $\mathbf{A} 2, \mathbf{A} 3$, A4, and A5. Note that particularly in the presence of $\alpha$-DTX and $\mathrm{Cd}^{2+}$ input resistance increases.

direction, and as a consequence, the membrane time constant increased. In addition to $1 \mu \mathrm{M}$ TTX and $30 \mathrm{nM} \alpha$-DTX, application of $0.25 \mathrm{mM} \mathrm{Cd}^{2+}$, a potent but non-specific calcium channel blocker, abolished the slow action potentials $(n=3)$ (Fig. $6 \mathrm{~A}(4))$, indicating that these were produced by a regenerative $\mathrm{Ca}^{2+}$ conductance $\left(g_{\mathrm{Ca}}\right)$ (Golding et al. 1999; Bal and Oertel 2001, 2007). As can be seen from the I-V relationship in Figure $6 \mathrm{~B}(2)$, the input resistance further increased in both the depolarizing and hyperpolarizing directions. The increase of input resistance in the hyperpolarizing direction could be due to a nonspecific effect of $\mathrm{Cd}^{2+}$ on hyperpolarization-activated, mixed-cation channels. In the presence of TTX, $\alpha$-DTX, and $\mathrm{Cd}^{2+}$, the further extracellular application of $30 \mu \mathrm{M} \mathrm{ZD} 7288$ blocked the sag of the membrane potential in response to hyperpolarizing current and increased the input resistance further (Fig. 6A(5), B(2)).

\section{Stellate and bushy cells physiology}

The finding that octopus cells have unusual properties raised the question whether those properties are characteristics specifically of octopus cells or whether they are a function of immaturity or a lack of health of slices. Therefore, ten recordings were made from stellate cells located in the AVCN of 15- or 16-day-old kittens, of which three were anatomically identified. The mean resting potential of the stellate cells was $-59.7 \pm$ $1.0 \mathrm{mV}(n=10)$. The mean input resistance and mean time constant were $157 \pm 35 \mathrm{M} \Omega(n=10)$ and $6.96 \pm$ $0.82 \mathrm{~ms}(n=10)$, respectively. The amplitude of action potentials was $76.2 \pm 3.35 \mathrm{mV}(n=10)$ and the mean duration of action potentials measured halfway between the peak and the inflection point was $0.47 \pm 0.06 \mathrm{~ms}(n=$ 10). Since only three of the recordings from stellate cells were morphologically identified, it was not possible to distinguish D- and T-stellate cells and the recordings were pooled for the analysis of basic membrane properties. Figure 7A shows the responses to depolarizing (A1) and hyperpolarizing current pulses (A2) and I-V relationship (A3) in one representative stellate cell. Stellate cells fired trains of action potentials with constant interspike intervals when they were depolarized by the injection of current. Increases in current strength increased the number of action potentials (Fig. 7A(1)). These recordings confirm that some cells in slices from cats were capable of firing repetitively and strengthen the conclusion that octopus cells are biophysically specialized.

Recordings were also made from six bushy cells located in AVCN of 15-day-old kittens, of which three were anatomically identified. Figure $7 \mathrm{~B}$ shows the responses to depolarizing and hyperpolarizing current pulses (B1) and I-V relationship (B2) in one representative bushy cell. Measurements of the basic membrane properties were performed in these bushy cells. The mean resting potential, input resistance, and time constant were $-61.1 \pm 1.9 \mathrm{mV}(n=6), 108.0 \pm$ $43.1 \mathrm{M} \Omega(n=6)$, and $7.6 \pm 0.3 \mathrm{~ms}(n=6)$, respectively. The amplitude of action potentials was $72.0 \pm 8.5 \mathrm{mV}$ 
A1
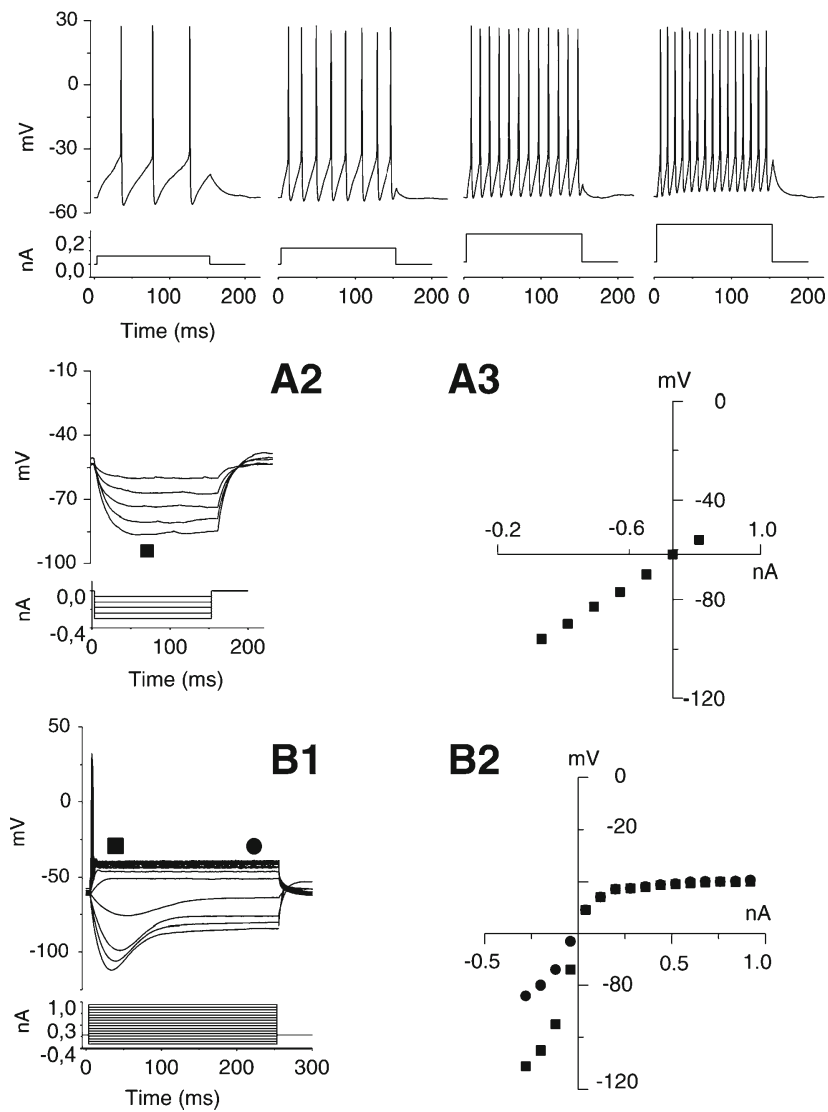

A3
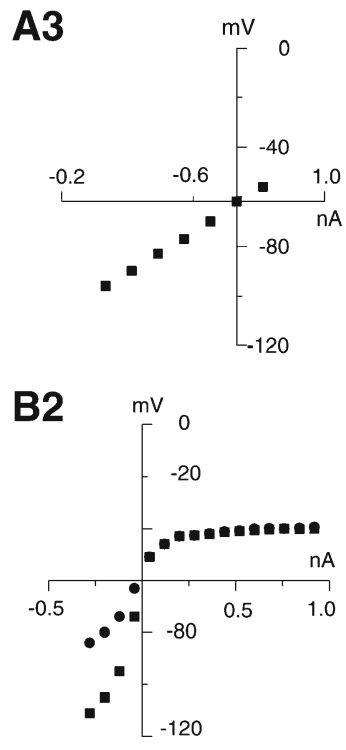

FIG. 7. Voltage responses of a stellate cell $(\mathbf{A})$ and a bushy cell (B) located in AVCN to DC current injections. A Voltage responses of a stellate cell to depolarizing current pulses (A1) and hyperpolarizing current pulses (A2). The I-V relationship for the same cell was plotted in A3, which was roughly linear over the subthreshold voltage range. B 1 Families of superimposed responses of a bushy cell to current pulses. Note that bushy cells fired only a single action potential at the onset of depolarizations, independent of the strength of the current and that hyperpolarizing current pulses produced voltage changes that sagged toward rest. B2 The peak and steady-state voltage responses were plotted as a function of current step. I-V relationships plotted from both the peak and the steady-state levels were nonlinear over particularly the whole depolarizing current range. The symbols indicate the positions in the traces from which the measurements were made.

$(n=6)$ and the mean duration of action potentials measured halfway between the peak and the inflection point was $0.68 \pm 0.11 \mathrm{~ms}(n=6)$. All the bushy cells fired only a single action potential at the onset of depolarizations, independent of the strength of the current (Fig. $7 \mathrm{~B}(1)$ ). A plot of the voltage changes at the end of current pulses as a function of the strength of the injected current reveals rectification in the depolarizing voltage range in every cell (Fig. $7 \mathrm{~B}(2)$ ). The amplitude of action potentials in the bushy cells was surprisingly large in the kitten compared to that in mice. Action potentials in bushy cells of mice that were recorded under comparable conditions have amplitudes between $25 \mathrm{mV}$ to $60 \mathrm{mV}$ with a mean of roughly $42 \mathrm{mV}$ in bushy cells of 18-20-day-old mice (unpublished results) (Oertel 1983; McGinley and Oertel 2006; Oertel and Fujino 2001; Cao et al. 2007). Therefore, the difference in the magnitude of action potentials in bushy cells in kittens and in mice could reflect either the immaturity of bushy cells in kittens or a species difference.

\section{DISCUSSION}

Octopus cells seem to be found in all mammalian ventral cochlear nuclei. The present study shows that the unusual electrophysiological features of octopus cells that have previously been described in mice are also found in cats, making it likely that they are a general property of octopus cells in mammals. Among mammalian neurons, octopus cells have among the lowest input resistances, the shortest time constants, and the largest $g_{\mathrm{KL}}$ and $g_{\mathrm{h}}$ known (Golding et al. 1995, 1999; Bal and Oertel 2000, 2001). Investigators have speculated that the unusual features of octopus cells that were revealed in slices from mice could underlie the precision in signaling that has been studied in cats in vivo (Golding et al. 1995; Oertel et al. 2000). Our study demonstrates directly that the electrophysiological properties of octopus cells in cats are similar to those in mice and suggests that low input resistances, short time constants, and large resting $g_{\mathrm{KL}}$ and $g_{\mathrm{h}}$ are general and characteristic features of octopus cells. Octopus cells in kittens fired only a single action potential in response to depolarizing current and exhibited a depolarizing sag in responses to hyperpolarizing current, as they do in mice. The application of blockers provides evidence for the existence of $g_{\mathrm{Na}}, g_{\mathrm{KL}}, g_{\mathrm{h}}$, and $g_{\mathrm{Ca}}$ conductances whose properties have been studied in mice (Bal and Oertel 2000, 2001, 2007; Cao and Oertel 2005). Comparisons between recordings from octopus cells in 7-day-old and 16-dayold kittens show that action potentials become shorter and briefer and that the rectification that is produced by $g_{\mathrm{KL}}$ and $g_{\mathrm{h}}$ in depolarizing and hyperpolarizing directions, respectively, becomes more pronounced and the input resistance decreases as kittens mature.

\section{Morphology of the octopus cell}

Octopus cells were named on the basis of studies of the cochlear nuclei of cats; staining of their proximal dendrites showed that dendrites of octopus cells emanate from one pole of the cell body and was the basis of their name (Osen 1969). Earlier studies had drawn attention to these neurons by various names. Cajal, for example, pointed out the "tail of the cochlear nucleus" in a Golgi-stained section from a 
rabbit (Cajal 1995). Working with Golgi stained preparations from cats, Lorente de Nó aptly called the octopus cell area the "interfascicular nucleus" (Lorente de No 1933, 1981). Also working with young cats, Morest and his colleagues made the first detailed descriptions of octopus cells, showing that in cats octopus cell bodies and proximal dendrites are sometimes covered with spine-like protrusions (Kane 1973; Brawer et al. 1974; Rhode et al. 1983). It soon became apparent that octopus cells are a feature of all mammalian $\mathrm{CN}$. Their presence has been documented not only in cats and rabbits but also in humans (Adams 1986, 1997), guinea pigs (Hackney et al. 1990), and mice (Willott and Bross 1990; Golding et al. 1995, 1999).

Octopus cells have common anatomical features that were also observed in the present studies. They are found in the caudal part of the VCN. Most are within a well-defined octopus cell area but a recent report indicates that they may spread ventrally along the caudal surface in mice (Oertel et al. 2008). The dendrites of octopus cells are thick, emanate from one pole of the cell body reaching rostralward, dorsalward, and laterally. Dendrites often, but not always, have tapering tertiary dendrites. A curious but inconsistent feature of octopus cells is the spine-like thorny protrusions that have been observed on the surfaces of some octopus cell bodies and proximal dendrites. The spine-like thorny protrusions observed on the surfaces of some cat octopus cell bodies and proximal dendrites in the current study have also been reported previously in several studies of cats (Kane 1973; Brawer et al. 1974; Rhode et al. 1983).

In mice, where the tonotopic axis can be visualized in the parasagittal plane, it was shown that the dendrites of octopus cells have a consistent relationship with the tonotopic organization of the auditory nerve. The cell bodies of octopus cells lie caudally between fascicles of fibers that encode low frequencies whereas the dendrites reach anteriorly so that the tips lie among fibers that encode the highest frequencies (McGinley et al. 2005). In cats, low frequencies are represented ventrally and caudally whereas higher frequencies are represented more dorsally and rostrally. The isofrequency laminae are tipped with respect to the standard coronal, parasagittal, and horizontal planes (Snyder and Leake 1988; Leake and Snyder 1989; Leake et al. 2002). Our findings confirm those of others that show dendrites of octopus cells extending largely rostrally and dorsally from the cell body across the path of auditory nerve fibers (Smith et al. 2005; Rhode et al. 1983).

\section{Membrane properties of octopus cells}

The biophysical properties of octopus cells in 15- or 16-day-old cats CN resemble octopus cells of 18-day- old mice (Golding et al. 1995, 1999; Oertel et al. 2000; Bal and Oertel 2000, 2001, Cao and Oertel 2005). Similarities include low input resistance, short time constant, firing at the onset of depolarizing current pulses, depolarizing sags of the membrane potential towards the resting value in responses to hyperpolarizing current pulses, and demonstrable calcium action potentials in the presence of $\alpha$-DTX. However, the properties of the octopus cells from these two different species are not identical. Table 1 compares firing patterns, resting potentials, input resistances, time constants, and amplitudes of action potentials of VCN principal neurons in cats and mice. The mean input resistance of octopus cells in 16-day-old kittens was twofold greater than in 18-day-old mice $(15.8 \pm 1.5 \mathrm{M} \Omega$ vs. $6.7 \pm 0.3 \mathrm{M} \Omega$ in mice) (Bal and Oertel 2000).

In response to sustained depolarizations, cat octopus cells fire a single action potential (see Fig. 3), but a second action potential can be induced in octopus cells if the cell is depolarized with an increasing current step (see Fig. 4A). This indicates that octopus cells are not in an absolute but rather in a relative refractory state after the first action potential during sustained depolarization as has been reported previously in mice (Oertel et al. 2000).

Octopus cells are able to fire repetitively at exceptionally rapid rates. Octopus cells of the mouse $\mathrm{CN}$ can fire one action potential with every pulse to trains of depolarizing current pulses at up to about $1,000 \mathrm{~Hz}$ in vitro (Oertel et al. 2000). In vitro octopus cells of cats can fire at up to about $800 \mathrm{~Hz}$ as they can in vivo (Rhode and Smith 1986).

\section{Maturation of octopus cells}

It is likely that octopus cells are not fully mature in 16-day-old kittens. Between 7 and 16 days after birth, the biophysical properties of octopus cells change substantially; the input resistance is reduced, the sag in voltage toward rest in response to hyperpolarizing current increases, and the non-linearity in the $\mathrm{V}-\mathrm{I}$ relationship in the depolarizing direction increases. Also, action potentials become shorter and briefer. These changes suggest that as octopus cells in kittens mature, $g_{\mathrm{KL}}$ and $g_{\mathrm{h}}$ increase, and that the increase in $g_{\mathrm{KL}}$ could shorten and sharpen action potentials. The direction of the trend indicates that octopus cells in mature cats have lower input resistances, shorter time constants, and briefer action potentials than those we recorded. In mice and rats, which mature more quickly than cats, such trends have been documented in other types of neurons in auditory brainstem nuclei (Wu and Oertel 1987; Taschenberger and von Gersdorff 2000).

Recordings from auditory nerve fibers in vivo show that maturation of most functional characteristics takes place over several weeks after birth and in some 
cases continues after the first postnatal month. At birth, auditory thresholds are high and then are reduced so that they reach adult values at about 22 days after birth. Maximal discharge rates and latencies also reach adult values at the beginning of the third week after birth (Brugge et al. 1978, 1981; Romand 1984; Dolan et al. 1985; Kettner et al. 1985; Walsh and McGee 1987). Phase-locking, however, which depends critically on the temporal precision in firing, matures only toward the end of the third postnatal week (Brugge et al. 1978; Kettner et al. 1985; Woolf and Ryan 1985). The response patterns of the neurons in adult cats are however recognizable in immature ones (Roman and Marty 1975; Brugge et al. 1978; Brugge and OConnor 1984; Woolf and Ryan 1985). What the changes are in response properties of octopus cells, cells with "onsetinitial" peristimulus-time histograms, is not known.

In immature cats, not only the intrinsic properties but also the synaptic inputs are likely to be less sharply timed than after they mature. Synaptic responses in the auditory system become briefer and more sharply timed as they mature (Wu and Oertel 1987; Taschenberger and von Gersdorff 2000).

From these considerations, it is reasonable to conclude that octopus neurons of 15- and 16-day-old cats appear to share many characteristic features with the octopus cells of mouse $\mathrm{CN}$, however even in 15and 16-day-old kittens, octopus cells are probably not fully mature (Golding et al. 1995, 1999; Bal and Oertel 2000; Cao and Oertel 2005).

\section{Conductances of octopus cells}

The single action potential that fired at the onset of a stimulus in cat octopus cells was blocked by TTX, indicating that action potentials in octopus cells are generated by conventional, regenerative, $\mathrm{Na}^{+}$currents, as observed in the mouse (Golding et al. 1999). In the presence of TTX, depolarizing currents evoke a transient, depolarizing "hump" in octopus cells of cats. The hump was not blocked by $\mathrm{Cd}^{2+}$, indicating that it was not generated by a voltage-sensitive calcium current. It may have been generated by a voltage-sensitive potassium current as has been demonstrated in bushy cells (Schwarz and Puil 1997).

Mouse octopus cells have exceptionally strong $g_{\mathrm{h}}$ and $g_{\mathrm{KL}}$, which are closely associated with the low input resistance of the octopus cells (Golding et al. 1995, 1999; Oertel et al. 2000; Bal and Oertel 2000, 2001; Cao and Oertel 2005, Oertel et al. 2008). In the present study the outward rectification in responses to depolarizing current pulses was found to be sensitive to $\alpha$-DTX. $\alpha$-DTX selectively blocks potassium channels of the Shaker (Kv1) family that form $g_{\mathrm{KL}}$ (Dolly and Parcej 1996; Bal and Oertel 2001). The presence of large $g_{\mathrm{KL}}$ is a common feature of auditory neurons encoding timing with temporal precision. $g_{\mathrm{KL}}$ prevents repetitive firing, contributes to the repolarization of action potentials and synaptic potentials to sharpen their peaks and makes neurons sensitive to the rate at which they are depolarized (Oertel 1983; Manis and Marx 1991; Reyes et al. 1996; Golding et al 1999; Oertel et al. 2000; Ferragamo and Oertel 2002; Brew et al. 2003; Barnes-Davies et al. 2004; Leao et al. 2004; Scott et al. 2005; Kuba et al. 2005; McGinley and Oertel 2006; Cao et al. 2007).

The deletion of the depolarizing sag by ZD7288 indicates that the conductance that underlies the sag is $g_{\mathrm{h}}$, since ZD7288 is a selective blocker of hyperpolarization-activated, mixed cation current (Khakh and Henderson 1998; Bal and Oertel 2000). The depolarizing shift of the membrane potential by 4-AP

\section{TABLE 1}

Comparisons of some membrane properties of VCN principal neurons in 16-day-old cats and 18-day-old mice (mean \pm SE)

\begin{tabular}{lllcccc}
\hline & & Firing pattern & $\begin{array}{l}\text { Resting potential } \\
(\mathrm{m} V)\end{array}$ & $\begin{array}{l}\text { Input resistance } \\
(\mathrm{M} \Omega)\end{array}$ & $\begin{array}{l}\text { Time constant } \\
(\mathrm{ms})\end{array}$ & $\begin{array}{c}\text { Amplitude of action } \\
\text { potentials }(\mathrm{mV})\end{array}$ \\
\hline Octopus cells & Mouse & Onset $^{\mathrm{a}}$ & $-61.8 \pm 1.7^{\mathrm{a}}$ & $6.7 \pm 0.3^{\mathrm{a}}$ & $0.21 \pm 0.02^{\mathrm{a}}$ & $26.0 \pm 0.9^{\mathrm{a}}$ \\
& Cat & Onset $^{\mathrm{a}}$ & $-59.4 \pm 0.4$ & $15.8 \pm 1.5$ & $1.28 \pm 0.3$ & $43.1 \pm 3.0$ \\
Bushy cells & Mouse & Onset $^{\mathrm{b}}$ & $-64.3 \pm 0.7^{\mathrm{b}}$ & $67.2 \pm 17.1^{\mathrm{c}}$ & $0.6-2^{\mathrm{c}}$ & $28(25-60)^{\mathrm{d}}$ \\
& Cat & Onset $^{\mathrm{c}}$ & $-61.1 \pm 1.9$ & $108.0 \pm 43.1$ & $7.6 \pm 0.3$ & $72.0 \pm 8.5$ \\
& Mouse & Sustained & $-59.2 \pm 0.3^{\mathrm{e}}$ & $74 \pm 11^{\mathrm{f}}$ & - & $58(25-60)^{\mathrm{d}}$ \\
& Cat & Sustained & $-59.7 \pm 1.0$ & $157 \pm 35$ & $6.96 \pm 0.82$ & $76.2 \pm 3.35$ \\
\hline
\end{tabular}

${ }^{\mathrm{a} B a l}$ and Oertel 2000

${ }^{\mathrm{b}}$ McGinley and Oertel 2006

${ }^{\mathrm{c}} \mathrm{Cao}$ et al. 2007

${ }^{\mathrm{d} O e r t e l} 1983$

éFujino and Oertel 2001

${ }^{f}$ Rodrigues and Oertel 2006 
and $\alpha$-DTX and a hyperpolarizing shift by ZD7288 in cat octopus cells imply that $I_{\mathrm{KL}}$ and $I_{\mathrm{h}}$ are activated at rest and oppose one another, together setting the resting potential. This is consistent with earlier reports (Golding et al 1995, 1999; Bal and Oertel 2000, 2001; Oertel et al. 2000).

As in mice, octopus cells of the cat also have a voltage-sensitive calcium conductance (Golding et al. 1999; Bal and Oertel 2007). Since it is small in amplitude relative to other voltage-sensitive currents and is slow relative to the duration of voltage changes in octopus cells, the contribution of the voltage-gated $\mathrm{Ca}^{2+}$ currents to electrical signaling at the cell body is probably minor. Bal and Oertel (2007) suggested that the entry of calcium ions might serve as a measure of activity and might drive homeostatic mechanisms.

\section{Functional implication of the conductances in octopus cells of cat $\mathrm{CN}$}

Responses to sounds by octopus cells comprise the interaction of synaptic currents with the intrinsic properties. Octopus cells are biophysically specialized to respond rapidly and with temporal precision to synchronous excitatory synaptic inputs from the auditory nerve fibers. The activation of $g_{\mathrm{h}}$ and $g_{\mathrm{KL}}$ at rest results in low input resistance (Golding et al. 1995, 1999; Oertel et al. 2000; Bal and Oertel 2000, 2001; Cao and Oertel 2005). The low input resistances of octopus cells have important consequences for the signaling, in that they allow synaptic currents to produce rapid and brief post synaptic voltage changes. The brevity and rapidity of voltage changes make the signaling of octopus cells temporally precise. Another feature that contributes to the temporal precision in signaling is that octopus cells fire only when the synchronous activation of multiple inputs sums to produce a sufficiently rapid depolarization (Golding et al. 1995). Temporal jitter in the firing of individual auditory nerve inputs is thereby reduced by averaging. A further reduction in temporal jitter arises because action potentials are often evoked by the rate of rise of EPSPs rather than at their peaks (Ferragamo and Oertel 2002; McGinley and Oertel 2006). The rate of depolarization is fastest when the rising phases of auditory nerve inputs sum; as the rising phases of EPSPs form only a brief segment of the entire synaptic response, the summing of rising phases, too, is sharply timed.

Membrane properties of the stellate and bushy cells of cats

In the present study, some of the basic membrane properties of stellate and bushy cells of 15- or 16-dayold cat CN closely resemble those in cells of 18-day-old mouse CN (see Table 1). Resting membrane potentials and action potentials were comparable, but again, input resistances were larger and time constants were longer in stellate and bushy cells in comparison to those of mice (Rodrigues and Oertel 2006; Cao et al. 2007; Wu and Oertel 1987). In the present study, in response to depolarizing current pulses, stellate cells of kittens had a similar response pattern to those of mice, firing trains of action potentials with constant interspike intervals. Increases in current strength increased the number of action potentials ( $\mathrm{Wu}$ and Oertel 1984; Rodrigues and Oertel 2006; Ferragamo et al. 1998). Similarity between responses of bushy cells of kittens and mice to depolarizing and hyperpolarizing current injections were also striking. Firing at the onset of depolarizing current pulses, rectification in the depolarizing voltage range and depolarizing sags of the membrane potential towards the resting value in responses to hyperpolarizing current pulses were common response properties in mice and kittens $(\mathrm{Wu}$ and Oertel 1987; Cao et al. 2007).

\section{ACKNOWLEDGEMENTS}

We are grateful to Prof. Donata Oertel for her guidance and support in setting up the electrophysiology lab. We thank Prof. Ray W. Guillery as well as Prof. Donata Oertel for reading the manuscript and making suggestions for its improvement. We also thank Xiao-Jie Cao for her assistance in solving problems during setting up the patch clamp system. This work was supported by a grant from TUBITAK, 105 O 215 (Turkey).

\section{REFERENCES}

ADAms JC. Neuronal morphology in the human cochlear nucleus. Arch. Otolaryngol. Head Neck Surg 112(12):1253-1261, 1986.

ADAms JC. Projections from octopus cells of the posteroventral cochlear nucleus to the ventral nucleus of the lateral lemniscus in cat and human. Auditory Neurosci 3:335-350, 1997.

AdAMs JC, WarR WB. Origins of axons in the cat's acoustic striae determined by injection of horseradish peroxidase into severed tracts. J. Comp. Neurol. 170:107-122, 1976.

BAL R, OerTel D. Hyperpolarization-activated, mixed-cation current (Ih) in octopus cells of the mammalian cochlear nucleus. J. Neurophysiol. 84:806-817, 2000.

Bal R, Oertel D. Potassium currents in octopus cells of the mammalian cochlear nuclei. J. Neurophysiol. 86:2299-2311, 2001.

BAL R, OERTEL D. Voltage-activated calcium currents in octopus cells of the mouse cochlear nucleus. J. Assoc. Res. Otolaryngol. 8 (4):509-521, 2007.

Bal R, Janahmadi M, Green GG, Sanders DJ. Effect of calcium and calcium channel blockers on transient outward current of F76 and D1 neuronal soma membranes in the subesophageal ganglia of Helix aspersa. J. Membr. Biol. 173(3):179-185, 2000.

Bal R, Janahmadi M, Green GG, Sanders DJ. Two kinds of transient outward currents, I(A) and I(Adepol), in F76 and D1 soma 
membranes of the subesophageal ganglia of Helix aspersa. J. Membr. Biol. 179(1):71-78, 2001.

Bal R, Green GG, Rees A, Sanders DJ. Firing patterns of inferior colliculus neurons-histology and mechanism to change firing patterns in rat brain slices. Neurosci. Lett. 317(1):42-46, 2002.

Barnes-Davies M, Barker MC, Osmani F, Forsythe ID. Kv1 currents mediate a gradient of principal neuron excitability across the tonotopic axis in the rat lateral superior olive. Eur. J. Neurosci. 19:325-333, 2004.

Brawer JR, Morest DK, Kane EC. The neuronal architecture of the cochlear nucleus of the cat. J. Comp. Neurol. 155:251-300, 1974.

Brew HM, Hallows JL, Tempel BL. Hyperexcitability and reduced low threshold potassium currents in auditory neurons of mice lacking the channel subunit Kv1.1. J. Physiol. 548:1-20, 2003.

Brugge JF, O'Connor TA. Postnatal functional development of the dorsal and posteroventral cochlear nuclei of the cat. J. Acoust. Soc. Am. 75(5):1548-1562, 1984.

Brugge JF, Javel E, Kitzes LM. Signs of functional maturation of peripheral auditory system in discharge patterns of neurons in anteroventral cochlear nucleus of kitten. J. Neurophysiol. 41 (6):1557-1559, 1978.

Brugge JF, Kitzes LM, Javel E. Postnatal development of frequency and intensity sensitivity of neurons in the anteroventral cochlear nucleus of kittens. Hear Res. 5(2-3):217-229, 1981.

Cajal SR. Histology of the Nervous System. New York, Oxford University Press, 1995.

CaO X, Oertel D. Temperature affects voltage-sensitive conductances differentially in octopus cells of the mammalian cochlear nucleus. J. Neurophysiol. 94:821-832, 2005.

Cao XJ, Shatadal S, Oertel D. Voltage-sensitive conductances of bushy cells of the Mammalian ventral cochlear nucleus. J. Neurophysiol. 97(6):3961-3975, 2007.

Dolan DF, Teas DC, Walton JP. Postnatal development of physiological responses in auditory nerve fibers. J. Acoust. Soc. Am. 78 (2):544-554, 1985.

Dolly JO, PARCEJ DN. Molecular properties of voltage-gated K+ channels. J. Bioenerg. Biomembr. 28(3):231-253, 1996.

EHRET G. Comparative psychoacoustics: perspectives of peripheral sound analysis in mammals. Naturwissenschaften. 64(9):461-470, 1977.

FAY RR. Comparative psychoacoustics. Hear. Res. 34(3):295-305, 1988.

Ferragamo MJ, Oertel D. Octopus cells of the mammalian ventral cochlear nucleus sense the rate of depolarization. J. Neurophysiol. 87:2262-2270, 2002.

Ferragamo MJ, Golding NL, Oertel D. Synaptic inputs to stellate cells in the ventral cochlear nucleus. J. Neurophysiol. 79(1):5163, 1998.

Forscher P, Oxford GS. Modulation of calcium channels by norepinephrine in internally dialyzed avian sensory neurons. J. Gen. Physiol. 85(5):743-763, 1985.

Gardner SM, Trussell LO, Oertel D. Time course and permeation of synaptic AMPA receptors in cochlear nuclear neurons correlate with input. J. Neurosci. 19:8721-8729, 1999.

Godfrey DA, KIANG NYS, Norris BE. Single unit activity in the posteroventral cochlear nucleus of the cat. J. Comp. Neurol. 162:247-268, 1975.

Golding NL, Robertson D, Oertel D. Recordings from slices indicate that octopus cells of the cochlear nucleus detect coincident firing of auditory nerve fibers with temporal precision. J. Neurosci. 15:3138-3153, 1995.

Golding NL, Ferragamo MJ, Oertel D. Role of intrinsic conductances underlying responses to transients in octopus cells of the cochlear nucleus. J. Neurosci. 19:2897-2905, 1999.

HackNey CM, Osen KK, Kolston J. Anatomy of the cochlear nuclear complex of guinea pig. Anat.-Embryol.-(Berl). 182:123-149, 1990.
Heffner HE, Heffner RS. Hearing ranges of laboratory animals. J. Am. Assoc. Lab. Anim. Sci. 46(1):11-13, 2007.

Kane EC. Octopus cells in the cochlear nucleus of the cat: heterotypic synapses upon homeotypic neurons. Int. J. Neurosci. 5(6):251-279, 1973.

Kettner RE, Feng JZ, Brugge JF. Postnatal development of the phase-locked response to low frequency tones of auditory nerve fibers in the cat. J. Neurosci. 5(2):275-283, 1985.

Khakh BS, Henderson G. Hyperpolarization-activated cationic currents (Ih) in neurones of the trigeminal mesencephalic nucleus of the rat. J. Physiol. (Lond.). 510:695-704, 1998.

Kuba H, Yamada R, Fukui I, Ohmori H. Tonotopic specialization of auditory coincidence detection in nucleus laminaris of the chick. J. Neurosci. 25:1924-1934, 2005.

LEAKE PA, SNYDER RL. Topographic organization of the central projections of the spiral ganglion in cats. J. Comp. Neurol. 281:612-629, 1989.

Leake PA, Snyder RL, Hradek GT. Postnatal refinement of auditory nerve projections to the cochlear nucleus in cats. J. Comp. Neurol. 448(1):6-27, 2002.

Leao RN, Berntson A, Forsythe ID, Walmsley B. Reduced low-voltage activated $\mathrm{K}+$ conductances and enhanced central excitability in a congenitally deaf (dn/dn) mouse. J. Physiol. 559:25-33, 2004.

LORENTE DE No R. Anatomy of the eighth nerve. III. General plans of structure of the primary cochlear nuclei. Laryngoscope 43:327350, 1933.

Lorente De No R. The Primary Acoustic Nuclei. New York, Raven Press, 1981.

Manis PB, MaRx SO. Outward currents in isolated ventral cochlear nucleus neurons. J. Neurosci. 11:2865-2880, 1991.

McGinley MJ, Oertel D. Rate thresholds determine the precision of temporal integration in principal cells of the ventral cochlear nucleus. Hear Res 216-217:52-63, 2006.

McGinley MJ, Lazimy YM, Bal R, Oertel D. Measurement and modeling of cable properties and optimal input delay profiles in octopus cells of the ventral cochlear nucleus. Ass. Res. Otolaryngol. 2005.

Morest DK, Hutson KA, Kwok S. Cytoarchitectonic atlas of the cochlear nucleus of the chinchilla, Chinchilla laniger. J. Comp. Neurol. 300:230-248, 1990.

Oertel D. Synaptic responses and electrical properties of cells in brain slices of the mouse anteroventral cochlear nucleus. J. Neurosci. 3:2043-2053, 1983.

Oertel D. Encoding of timing in the brain stem auditory nuclei of vertebrates. Neuron 19:959-962, 1997.

Oertel D, Fujino K. Role of biophysical specialization in cholinergic modulation in neurons of the ventral cochlear nuclei. Audiol. Neurootol. 6(4):161-166, 2001.

Oertel D, Bal R, Gardner SM, Smith PH, Joris PX. Detection of synchrony in the activity of auditory nerve fibers by octopus cells of the mammalian cochlear nucleus. Proc. Nat. Acad. Sci. U S A. 97:11773-11779, 2000.

Oertel D, Shatadal S, Cao XJ. In the ventral cochlear nucleus Kvl.1 and subunits of HCN1 are colocalized at surfaces of neurons that have low-voltage-activated and hyperpolarization-activated conductances. Neuroscience 154(1):77-86, 2008, 12.

Osen KK. Cytoarchitecture of the cochlear nuclei in the cat. J. Comp. Neurol. 136:453-484, 1969.

Reyes AD, Rubel EW, SPAIN WJ. In vitro analysis of optimal stimuli for phase-locking and time-delayed modulation of firing in avian nucleus laminaris neurons. J. Neurosci. 16:993-1007, 1996.

Rhode WS, Sмith PH. Encoding timing and intensity in the ventral cochlear nucleus of the cat. J. Neurophysiol. 56:261-286, 1986.

Rhode WS, Oertel D, SMith PH. Physiological response properties of cells labeled intracellularly with horseradish peroxidase in cat ventral cochlear nucleus. J. Comp. Neurol. 213:448-463, 1983. 
Ritz LA, Brownell WE. Single unit analysis of the posteroventral cochlear nucleus of the decerebrate cat. Neuroscience. 7 (8):1995-2010, 1982.

Rodrigues AR, OERTEL D. Hyperpolarization-activated currents regulate excitability in stellate cells of the mammalian ventral cochlear nucleus. J. Neurophysiol. 95(1):76-87, 2006.

RomAND R. Functional properties of auditory-nerve fibers during postnatal development in the kitten. Exp. Brain. Res. 56(3):395402, 1984.

Romand R, Marty R. Postnatal maturation of the cochlear nuclei in the cat: a neurophysiological study. Brain Res. 83(2):225-233, 1975.

Rouiller EM, RYugo DK. Intracellular marking of physiologically characterized cells in the ventral cochlear nucleus of the cat. J. Comp. Neurol. 225(2):167-186, 1984. [This paper includes no octopus cells!].

SCHOFIELD BR. Projections from the cochlear nucleus to the superior paraolivary nucleus in guinea pigs. J. Comp. Neurol. 360:135$149,1995$.

SCHOFIELD BR, CANT NB. Ventral nucleus of the lateral lemniscus in guinea pigs: cytoarchitecture and inputs from the cochlear nucleus. J. Comp. Neurol. 379:363-385, 1997.

Schwarz DW, PuIL E. Firing properties of spherical bushy cells in the anteroventral cochlear nucleus of the gerbil. Hear. Res. 114(12):127-138, 1997.

Scott LL, Mathews PJ, Golding NL. Posthearing developmental refinement of temporal processing in principal neurons of the medial superior olive. J. Neurosci. 25:7887-7895, 2005.
Smith PH, Massie A, Joris PX. Acoustic stria: anatomy of physiologically characterized cells and their axonal projection patterns. J. Comp. Neurol. 482:349-371, 2005.

SNYDER RL, LEAKE PA. Intrinsic connections within and between cochlear nucleus subdivisions in cat. J. Comp. Neurol. 278:209$225,1988$.

TASChENBERger H, vON GERSDORFF H. Fine-tuning an auditory synapse for speed and fidelity: developmental changes in presynaptic waveform, EPSC kinetics, and synaptic plasticity. J. Neurosci. 20:9162-9173, 2000.

Walsh EJ, McGeE J. Postnatal development of auditory nerve and cochlear nucleus neuronal responses in kittens. Hear. Res. 28 (1):97-116, 1987.

Wickesberg RE, Oertel D. Tonotopic projection from the dorsal to the anteroventral cochlear nucleus of mice. J. Comp. Neurol. 268:389-399, 1988.

Willott JF, Bross LS. Morphology of the octopus cell area of the cochlear nucleus in young and aging C57BL/6J and CBA/J mice. J. Comp. Neurol. 300:61-81, 1990.

WoOlF NK, Ryan AF. Ontogeny of neural discharge patterns in the ventral cochlear nucleus of the mongolian gerbil. Brain Res. 349 (1-2):131-147, 1985 .

Wu SH, OERTEL D. Intracellular injection with horseradish peroxidase of physiologically characterized stellate and bushy cells in slices of mouse anteroventral cochlear nucleus. J. Neurosci. 4 (6):1577-1588, 1984.

Wu SH, Oertel D. Maturation of synapses and electrical properties. Hear. Res. 30:99-110, 1987. 